
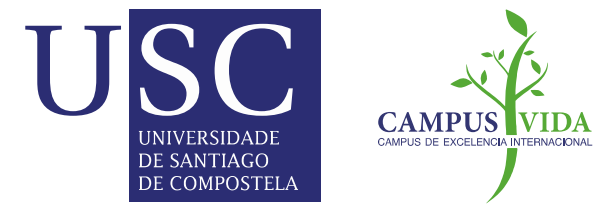

\title{
Opportunities for rotating belt filters in novel wastewater treatment plant configurations
}

Anton Taboada-Santos, Juan M. Lema and Marta Carballa

\section{Accepted Manuscript}

\section{How to cite:}

Taboada-Santos, A., Lema, J., \& Carballa, M. (2019). Opportunities for rotating belt filters in novel wastewater treatment plant configurations. Environmental Science: Water Research \& Technology, 5(4), 704-712. doi: 10.1039/c8ew00899j

\section{Copyright information:}

(C) The Royal Society of Chemistry 2019 


\section{Opportunities for rotating belt filters in novel wastewater treatment}

\section{3 plant configurations}

4 Anton Taboada-Santos*, Juan M. Lema and Marta Carballa

5 Department of Chemical Engineering, School of Engineering, Universidade de Santiago

6 de Compostela, E- 15782, Santiago de Compostela, Spain.

$7 \quad$ *Anton Taboada-Santos: corresponding author

$8 \quad$ E-mail: anton.taboada@usc.es

9 Tel: +34 881816021 ; Fax: +34881816702

10 E-mail addresses: anton.taboada@usc.es (A. Taboada-Santos), juan.lema@usc.es (J.M.

11 Lema), marta.carballa@usc.es (M. Carballa). 
Novel wastewater treatment plants (WWTPs), which are based on a partial nitritationanammox (PN-anammox) process, enable higher chemical oxygen demand (COD) recovery to produce biogas and lower treatment costs. In this study, rotating belt filters (RBFs) were examined in different configurations to identify the opportunities for RBFs to be included in novel WWTP configurations. RBFs enable recovery of $22-37 \%$ of the influent COD and removal of 34-56\% of hydrophobic organic micropollutants (OMPs). However, the effluent was not suitable for treatment in a $\mathrm{PN}$-anammox process due to its high COD. Chemically enhanced settling (CES) enabled these limitations to be overcome and caused an increase in OMP removal to 73-94\%. However, a dose of 300 $\mathrm{mg} / \mathrm{L}$ of ferric chloride was required to produce a suitable effluent for a $\mathrm{PN}$-anammox reactor. The combination of RBF and CES not only derived effluents suitable for treatment in PN-anammox units but also decreased the alkalinity consumption and the required chemical dose 3-fold to achieve comparable COD recovery and OMP removal. The methane yield of the combined sludges that were produced $\left(184 \mathrm{~L}(\mathrm{~N}) \mathrm{CH}_{4} / \mathrm{kg}\right.$ $\mathrm{COD}_{\text {influent }}$ ) was $75 \%$ higher than that obtained in conventional wastewater treatment (105 $\mathrm{L}(\mathrm{N}) \mathrm{CH}_{4} / \mathrm{kg} \mathrm{COD}_{\text {influent }}$ ), and the electricity requirements decreased from 0.54 to $0.41 \mathrm{kWh} / \mathrm{m}^{3}$ of treated wastewater. The energetic calculations showed that a WWTP incorporating this combined treatment could attain energy autarky with $29 \%$ lower operational costs than that of conventional treatment $\left(0.022\right.$ vs $\left.0.031 € / \mathrm{m}^{3}\right)$ as long as a minimum alkalinity-to-ammonium ratio of $1-1.25 \mathrm{~g}$ IC to $\mathrm{g} \mathrm{NH}_{4}{ }^{+}-\mathrm{N}$ was ensured in the effluent of the combined treatment. 
34 Keywords: cellulosic sludge, chemically enhanced settling, energy self-sufficiency, 35 organic matter recovery, organic micropollutants. 


\section{Introduction}

37 The discovery of the autotrophic nitrogen removal process (anammox process) ${ }^{1}$, which

38 does not require an organic carbon source for denitrification, introduces new possibilities for conceiving more energetically efficient wastewater treatment plants

40 (WWTPs). ${ }^{2}$ Although anammox-based processes are already applied at full scale to treat the supernatants of anaerobic sludge mesophilic digesters, the implementation of this technology in the mainstream of WWTPs is currently under investigation since they operate at considerably lower temperatures $\left(10-20^{\circ} \mathrm{C}\right) .^{3}$ In the first stage of these novel WWTPs, pre-concentration technologies can recover most of the chemical oxygen demand (COD) from sewage to produce energy (methane), which enables WWTPs to gain energy self-sufficiency or even become energyproducing facilities. ${ }^{4}$ Some studies have suggested that the energy contained in wastewater is nearly 5-fold the electrical energy that is used to drive conventional wastewater treatment. ${ }^{5}$ Therefore, as long as $20 \%$ of the total energy in domestic wastewater can be completely converted to electrical energy, WWTPs may be energetically self-sufficient.

The energy contained in wastewater can be recovered either directly in an anaerobic reactor in moderate climates ${ }^{6}$ or indirectly in an organic matter pre-concentration step in the form of sludge, which is subsequently treated by anaerobic digestion. Several preconcentration alternatives exist: physical (e.g., sieving), ${ }^{7}$ chemical (e.g., precipitation), ${ }^{8}$ biological (e.g., A-stage) ${ }^{9}$ or combinations of these alternatives.

57 Fine mesh rotating belt filters (RBFs) offer a very low footprint solution for recovering 
COD. They have been successfully applied as a replacement for conventional primary treatment (CPT) in traditional WWTPs ${ }^{10,11}$ and achieve total suspended solids (TSS) removals that are similar to those reported for $\mathrm{CPT}(\sim 50 \%){ }^{12,13} \mathrm{~A}$ maximum of $50 \%$ dry matter content of RBF sludge (also known as cellulosic sludge) can be achieved with a very high percentage of cellulose (maximum of 79\% of TSS), ${ }^{7}$ which facilitates its use as a soil conditioner in agriculture, fuel in a biomass-based power plant, and feed stock in the fermentation industry for the production of biofuels ${ }^{6}$ or chemicals, such as volatile fatty acids (VFA). ${ }^{14}$ However, the most straightforward method for onsite valorisation is energy recovery by mesophilic $\mathrm{AD} .{ }^{15}$

RBFs for municipal wastewater are commonly employed with a mesh size of 350 $\mu \mathrm{m} .{ }^{7,16}$ Their effluents show important COD content, which is derived not only from soluble COD that remain unaffected in the RBFs but also from particulate COD that corresponds to small TSS that pass the RBFs. Therefore, the implementation of additional steps prior to autotrophic nitrogen removal treatment is required. ${ }^{17}$ Chemically enhanced primary treatment (CEPT) or chemically enhanced settling (CES) is an alternative that overcomes the limitations of RBF. In CEPT processes, using some chemical additives (coagulants and/or flocculants), TSS and COD removal can eliminate a maximum of $90 \%$ and $70 \%$, respectively, of TSS and COD, and an increase in the sedimentation rate decreases the size of the settling tank. ${ }^{18}$ Chemical coagulation has been shown to completely eliminate viruses from wastewater. ${ }^{19}$ However, these processes require a considerable amount of chemicals and generate large volumes of sludge, with subsequent excessive costs of reagents and sludge disposal. ${ }^{20}$ 
Therefore, the combination of RBF and CEPT may have a synergistic effect that overcomes the limitations of separately applying both technologies. The first effect is the incapacity of RBF to achieve high COD removal efficiencies and generate suitable effluents for autotrophic nitrogen removal process, and the second effect is the large chemical doses that are required in CES processes to achieve this goal. ${ }^{21}$

The objective of this study is to assess the potential of RBFs to recover COD in novel WWTP configurations via its combination with a CES. The system was technically, energetically and economically evaluated. Considering the different characteristics of RBF sludge that influence the interaction with OMPs, an additional goal is to assess their fate in RBFs and compare it with the removal in conventional and chemically enhanced primary treatment.

\section{Materials and methods}

\section{RBF systems}

The technical performance of two RBF systems with a mesh size of $350 \mu \mathrm{m}$ and located in the Blaricum WWTP $\left(1,600 \mathrm{~m}^{3} / \mathrm{h}\right)$ and Aarle-Rixtel WWTP $\left(2,600 \mathrm{~m}^{3} / \mathrm{h}\right)$ in The Netherlands was evaluated. Influent, effluent and sludge samples were collected and stored at $4{ }^{\circ} \mathrm{C}$ in aluminium bottles prior to analysis. Wastewater samples were characterised in terms of total solids (TS, g TS/kg) and volatile solids (VS, g VS/kg), total suspended solids (TSS, g TSS $/ \mathrm{kg}$ ) and volatile suspended solids (VSS, g VSS/kg), total chemical oxygen demand $\left(\mathrm{COD}_{\text {tot }}, \mathrm{g} \mathrm{O}_{2} / \mathrm{L}\right)$ and soluble chemical oxygen demand ( $\mathrm{COD}_{\text {sol }}, \mathrm{g} \mathrm{O}_{2} / \mathrm{L}$ ), total Kjeldahl (TKN, g N-TKN/L), total ammonium nitrogen ( $\mathrm{g} \mathrm{N}$ TAN/L) and OMPs concentrations. Dewatered RBF sludge samples were collected in 
both WWTPs, whereas WWTP raw RBF sludge (the sludge generated in the RBF without the dewatering process) was sampled in the Aarle-Rixtel WWTP. The sludge samples were characterised in terms of TS, VS, COD ${ }_{\text {tot }}, \mathrm{TKN}$ and OMPs concentrations. Eighteen commonly employed OMPs with different physico-chemical properties were considered in this study: three musk fragrances, galaxolide (HHCB), tonalide (AHTN) and celestolide (ADBI); three anti-inflammatories, ibuprofen (IBP), naproxen (NPX) and diclofenac (DCF); four anti-biotics, sulfamethoxazole (SMX), trimethoprim (TMP), erythromycin (ERY) and roxithromycin (ROX); four neurodrugs, fluoxetine (FLX), carbamazepine (CBZ), diazepam (DZP) and citalopram (CTL); one endocrine disrupting compound, triclosan (TCS); and three hormones, estrone (E1), 17 -estradiol (E2) and 17 $\alpha$-ethinylestradiol (EE2).

\section{CES tests}

Chemically enhanced settling (CES) assays were carried out with both RBF influent and RBF effluent of the Aarle-Rixtel WWTP in a Jar-Test device with vessels that contain 1 L of liquid volume following the protocol described by Carballa et al. ${ }^{22}$, but without $\mathrm{pH}$ correction. The influence of the dose of ferric chloride $(0-300 \mathrm{mg} / \mathrm{L})$ on the removal of TSS, COD and OMPs was analysed at $25^{\circ} \mathrm{C}$. The test included an initial 3 min period of rapid stirring $(150 \mathrm{rpm})$ after the addition of the coagulant, followed by $5 \mathrm{~min}$ of slow mixing $(50 \mathrm{rpm})$ for emulsion breaking and floc formation and a 1 hour period without mixing for floc separation, after which $500 \mathrm{~mL}$ of supernatant were collected for the characterisation.

\section{Biomethane potential tests}


The biomethane potential (BMP) of the RBF sludge and of the sludges generated after RBF (settling without chemicals and chemically enhanced settling using $100 \mathrm{mg} / \mathrm{L}$ of ferric chloride) was carried out following a protocol that was described elsewhere. ${ }^{23}$ The inoculum was flocculant biomass $(11.8 \mathrm{~g} \mathrm{VS} / \mathrm{L})$ from the sludge anaerobic digester of a WWTP.

The assays were conducted in $500 \mathrm{~mL}$ bottles ( $375 \mathrm{~mL}$ of working volume) by triplicate and were carried out with an inoculum-to-substrate ratio (ISR) in terms of VS of 2. Methane production of the blank (inoculum without substrate) was also determined by triplicate. The reactors were filled with macro- and micro-nutrient solutions, and the $\mathrm{pH}$ was adjusted to 7.2-7.5 with $\mathrm{NaOH}$ or $\mathrm{HCl}$ when necessary. After flushing the head space with nitrogen, the bottles were incubated at $37^{\circ} \mathrm{C}$. Accumulated methane production was monitored over time to determine the COD fraction that was converted into methane. The assays continued until the methane production during three consecutive days was less than $1 \%$ of the total production. ${ }^{23}$ Methane production by each sludge was calculated as the difference between the average production in the bottles with substrate and the average production in the blank. BMP was calculated as the experimental ultimate methane production, which was expressed in $\mathrm{L}(\mathrm{N}) / \mathrm{kg}$ VS fed, where $\mathrm{N}$ denotes the normal conditions $\left(1 \mathrm{~atm}, 0^{\circ} \mathrm{C}\right)$. Anaerobic biodegradability was expressed as the percentage of the initial COD of the substrate converted to methane. At the end of the test, bottles were opened and the $\mathrm{pH}$ and VFAs concentrations were measured to confirm that acidification did not occur. 
A common approach to determining the fraction of OMPs sorbed onto sludge is the use of the solid-water distribution coefficient $\left(\mathrm{K}_{\mathrm{d}}, \mathrm{L} / \mathrm{kg}\right)$. A spike of the 18 selected compounds was performed on raw RBF sludge at different concentrations in the three tests. Sodium azide $(10 \mathrm{mg} / \mathrm{L})$ was added to avoid biological activity. After 12 hours of mixing at room temperature to achieve equilibrium conditions, the samples were centrifuged and liquid and solid phases were separately analysed, as explained in the section analytical methods of this document.

\section{Analytical methods}

COD, pH, PA, TA, TSS, VSS, TS, VS, N-TKN and N-TAN were determined according to standard methods. ${ }^{24}$ Total inorganic carbon (IC) concentrations were measured with a Shimadzu analyser (TOC-5000). In BMP tests, biogas production was measured by a pressure transducer (Centrepoint Electronics) and its composition was determined by gas chromatography (HP 5890 Series II). VFAs were measured by gas chromatography with flame ionisation detection (FIC, HP 5890A).

To determine the OMP concentrations in the wastewater samples, the latter were centrifuged, pre-filtered (AP4004705, Millipore) and filtered by $0.45 \mathrm{~mm}$ (HAWP04700, Millipore) before performing solid phase extraction (SPE) with $200 \mathrm{mg}$ OASIS HLB cartridges (Waters, Milford, MA, USA), as described by FernandezFontaina et al. ${ }^{25}$ The quantification of musk fragrances (HHCB, AHTN, ADBI), antiinflammatories (IBP, NPX, DCF) and endocrine disrupting compound TCS was accomplished using a gas chromatograph (Varian CP-3900) coupled with an ion trap spectrometer (Varian CG-2100). Antibiotics (ERY, ROX, SMX, TMP), neurodrugs 
(CTC Analytics) connected to a mass spectrometer API 4000 triple quadrupole (Applied Biosystems). ${ }^{26}$

For influents and effluents, the sample volume that was analysed was $1 \mathrm{~L}$, and the final volume of the extract was $3 \mathrm{~mL}$, which generated an enrichment factor (concentration in the extract compared with the source) of $333 \mathrm{~L}_{\text {supernatant }} / \mathrm{L}_{\text {extract. }}$. For the liquid phase of RBF sludge, the analysed volume was $100 \mathrm{~mL}$ and the final volume of extract was 3 $\mathrm{mL}$, which yielded an enrichment factor of $33 \mathrm{~L}_{\text {supernatant }} / \mathrm{L}_{\text {extract. }}$ The limits of quantification for each case are shown in Table S1 in Supporting Information. The frozen solid phases of the influent and effluent of RBF and raw and dewatered SS were lyophilised to perform ultrasonic solvent extraction following a procedure based on the procedure described by Alvarino et al. ${ }^{27}$ Three sequential extractions with methanol and two sequential extractions with acetone were performed on the freezedried samples (0.5-1 g). In each extraction, samples were sonicated for $15 \mathrm{~min}$ and centrifuged at $1500 \mathrm{rpm}$ for $5 \mathrm{~min}$. The resulting supernatants were combined and filtered through glass wool. The resulting volume was evaporated to $1 \mathrm{~mL}$ (TurboVap $\mathrm{LV}$, Biotage) flowing nitrogen $\left(200 \mathrm{kPa}, 30^{\circ} \mathrm{C}\right)$ and resuspended in $100 \mathrm{~mL}$ of Milli-Q water prior to SPE. SPE and OMPs quantification were performed as previously described for liquid samples. The enrichment factor was $166 \mathrm{~g}_{\text {sludge }} / \mathrm{L}_{\text {extract. }}$

\section{Results and discussion}

\section{Technical performance of RBF systems}


The physico-chemical characterisation of the influent and effluent of the two RBF sampled systems are shown in Table 1. Both influents showed similar average values of TSS (320 and $275 \mathrm{mg} / \mathrm{L})$, VSS (300 and $255 \mathrm{mg} / \mathrm{L})$, VS (600 and $570 \mathrm{mg} / \mathrm{L}$ ), COD tot $_{\text {tot }}$ (680 and $600 \mathrm{mg} \mathrm{O}_{2} / \mathrm{L}$ ), $\mathrm{COD}_{\text {sol }}\left(230\right.$ and $260 \mathrm{mg} \mathrm{O}_{2} / \mathrm{L}$ ) and TKN (87 and $75 \mathrm{mg}$ TKN $\mathrm{N} / \mathrm{L}$ ), which is consistent with previously reported values for the Blaricum WWTP ${ }^{7}$ and for other urban WWTPs in The Netherlands. ${ }^{28}$ Conversely, the TS concentration in the influent of the Blaricum WWTP $(770 \mathrm{mg} / \mathrm{L})$ was considerably lower than that measured in the influent of the Aarle-Rixtel WWTP $(1,260 \mathrm{mg} / \mathrm{L})$, which indicates a lower salts dissolved concentration.

The removal efficiency of TSS ( 50\%), VSS ( 50\%), COD sol $_{(\sim 0 \%)}$ and TKN $(\sim 10 \%)$ were similar in both RBF systems. Regarding $\mathrm{COD}_{\text {tot }}$, a higher removal efficiency (37\%) was determined in the Blaricum WWTP than in the Aarle-Rixtel WWTP (22\%), which is explained by its higher $\mathrm{COD}_{\text {sol-to- }} \mathrm{COD}_{\text {tot }}$ ratio. The removal efficiencies determined in this study are similar to those reported by other authors regardless of the $\mathrm{TKN},{ }^{7,17}$ for which the removal efficiencies achieved in both scenarios were approximately $10 \%$ - a value that is slightly higher than the that reported elsewhere $(\sim 1 \%)^{7}$

The physico-chemical properties of dewatered RBF sludge are shown in Table 2. TS (21.5-27.5\%), VS (20.0-25.8\%), $\mathrm{COD}_{\text {tot }}\left(273-356 \mathrm{~g} \mathrm{O}_{2} / \mathrm{kg}\right)$ and TKN/VS ratio (12-16 $\mathrm{mg} \mathrm{N} / \mathrm{g}$ VS) are in accordance with the values reported for RBF sludge from the Blaricum WWTP ${ }^{15}$. VS represents approximately $95 \%$ of the TS of the sludge, and the

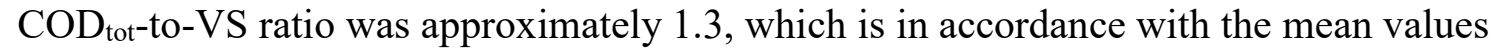


212 obtained by Paulsrud et al. ${ }^{29}$ for 19 Norwegian WWTPs that apply RBF technology.

213 Ghasimi et al. ${ }^{15}$ reported higher $\mathrm{COD}_{\text {tot }} / \mathrm{VS}$ ratios (1.6-1.8), which may be indicative of

214 a lower cellulose concentration.

215 Raw RBF sludge of the Aarle-Rixtel WWTP was ten times less concentrated than the

216 dewatered RBF sludge, which shows similar physico-chemical characteristics (data not

217 shown), as expected.

\section{Technical performance of CES}

219 The results of applying a CES to the influent of RBFs are shown in Figure 1. Ferric

220 chloride was selected as a coagulant rather than aluminium salts, considering its lower

221 price ${ }^{18}$ and lower required doses. ${ }^{22}$ Effluent quality that is comparable to that obtained

222 in RBFs was obtained after conventional settling $\left(\mathrm{COD}_{\text {tot }}\right.$ removal and TSS removal of

$223 \quad 36-38 \%$ and 47-49\%, respectively), without removal of $\mathrm{COD}_{\text {sol. }}$ By the addition of 100

$224 \mathrm{mg} / \mathrm{L}$ of ferric chloride, the removal of $\mathrm{COD}_{\text {tot }}$ and TSS increased to 66 and $86 \%$,

225 respectively. This decrease was primarily attributed to a large removal of suspended

226 matter, considering that the maximum $\mathrm{COD}_{\text {sol }}$ removal achieved did not exceed $25 \%$.

227 Heterotrophic denitrifiers may increase nitrogen removal efficiency in anammox

228 reactors with low influent $\mathrm{COD} / \mathrm{N}$ ratios $;{ }^{30}$ however, system failure was reported with

$229 \mathrm{COD} / \mathrm{N}$ ratios higher than 2 due to the growth of fast-growing heterotrophic denitrifiers,

230 which compete with the slow-growing anammox bacteria for nitrite. ${ }^{31}$ To fulfil this

231 condition, the required ferric chloride dose should be increased to $300 \mathrm{mg} / \mathrm{L}$, which is

232 similar to that reported by Carballa et al. ${ }^{22}$ 
RBFs are suitable to partial removal of $\mathrm{COD}_{\text {part }}$ from wastewater but they are unable to remove $\mathrm{COD}_{\text {sol. }}$ CES enables complete removal of $\mathrm{COD}_{\text {part }}$ and partial removal of

$236 \mathrm{COD}_{\text {sol }}$ with a requirement of high chemical doses. Thus, the combination of RBF and

237 CES was analysed (Figure 2) to attempt to overcome the limitation of both technologies

238 and compare with the CES system (Figure 1).

239 The combination of RBF followed by settling without chemicals addition produced a

240 removal of almost $100 \%$ of the $\mathrm{COD}_{\text {part }}$ of wastewater, whereas $50 \%$ of removal was

241 achieved when the test was carried out for the RBF influent (Figure 1), which may

242 indicate that the presence of cellulose in wastewater limits the settlement of other

243 suspended solids due to its tendency to float. $\mathrm{COD}_{\text {sol }}$ remained unaffected. When 100

$244 \mathrm{mg} / \mathrm{L}$ of ferric chloride were added, $\mathrm{COD}_{\text {part }}$ was totally removed, which generates an

245 effluent with approximately $10 \mathrm{mg}$ TSS/L, and more than $50 \%$ of $\mathrm{COD}_{\text {sol }}$ was removed

246 (Figure 2), which accounts for $\mathrm{COD}_{\text {tot }}$ removal of $84 \%$. To obtain comparable results

247 without an RBF system, a considerably higher dose of $\mathrm{FeCl}_{3}$ (approximately $300 \mathrm{mg} / \mathrm{L}$ )

248 was needed (Figure 1).

249 Note that a side effect exists of the addition of the coagulant on the alkalinity, with a

250 consumption of $22 \mathrm{mg}$ IC for each $100 \mathrm{mg}$ of $\mathrm{FeCl}_{3} .{ }^{32}$ Taking into account that the

251 further PN-anammox step requires a minimum alkalinity-to-ammonium ratio of 1-1.25

$252 \mathrm{~g} \mathrm{IC}$ per $\mathrm{g} \mathrm{NH}_{4}{ }^{+}-\mathrm{N},{ }^{33}$ the need for an external bicarbonate addition to avoid acidification

253 in the PN-anammox unit, which considers an ammonium concentration of $67 \mathrm{mg} \mathrm{NH}_{4}{ }^{+}-$

254 N/L (Table 1), would be much higher if the RBF system is not present.

255 Biomethane potential of the sludges 

generated after RBFs (settling without chemicals and settling with the addition of 100 $\mathrm{mg} / \mathrm{L}$ of ferric chloride). Three of the sludges showed similar methane production rates and needed 26 days to complete the test, following the criteria proposed by Holliger et al. ${ }^{23}$ The neutral $\mathrm{pH}$ values (7.3-7.7) and the absence of VFA $(<2.5 \mathrm{ppm}$ acetic acid $)$ at the end of the tests (data not shown) indicated that the performance of the tests was adequate and acidification did not occur.

Dewatered RBF sludge showed the highest BMP value (386 L(N) $\mathrm{CH}_{4} / \mathrm{kg}$ VS), which is consistent with other results in the literature. ${ }^{29}$ However, the anaerobic biodegradability (80\%) was higher than that the obtained by Ghasimi et al. ${ }^{15}(64 \%)$, which is explained by its lower $\mathrm{COD}_{\text {tot }} / \mathrm{VS}$ ratio.

The sludges generated during conventional settling and CES after RBF showed similar BMP values $\left(327 \mathrm{~L}(\mathrm{~N}) \mathrm{CH}_{4} / \mathrm{kg}\right.$ VS and $310 \mathrm{~L}(\mathrm{~N}) \mathrm{CH}_{4} / \mathrm{kg}$ VS, which corresponds to $60 \%$ of anaerobic biodegradability and $58 \%$ of anaerobic biodegradability, respectively), but values lower than those for dewatered RBF sludge. These values are comparable to those reported for conventional primary sludge (259-325 L (N) CH4/kg VS). ${ }^{29}$ Thus, the installation of RBFs seems to not affect the BMP of sludge obtained by conventional settling, which may be explained by the low proportion of cellulose recovered in the latter system. ${ }^{7}$ The similar results obtained for both sludges do not agree with those obtained by Kooijman et al., ${ }^{34}$ who reported an important increase in the BMP of the sludge generated during CES compared with conventional settling due to the higher readily degradable biomass removed by flocculation. However, Romero- 
Güiza et al. ${ }^{35}$ reported that $\mathrm{Fe}^{3+}$ reduction can limit the conversion of organics to methane as $\mathrm{Fe}^{3+}$ reduction is more thermodynamically favourable than methanogenesis. The data from the BMP test and the results of the CES tests enabled calculation of the methane production of each sludge in relation to the COD recovery in each treatment

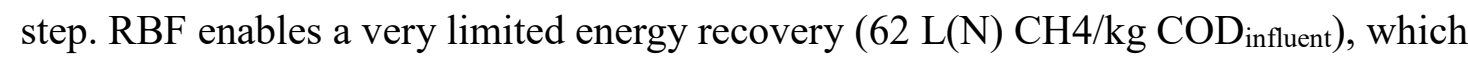
is explained by lower $\mathrm{COD}_{\text {tot }}$ recovery compared with that of other tested technologies (Figure 2).

The system RBF followed by settlement without chemicals enabled an increase in the energy recovery to $85 \mathrm{~L}(\mathrm{~N}) \mathrm{CH}_{4} / \mathrm{kg} \mathrm{COD}_{\text {influent }}$. However, the highest energy recovery was achieved with the combination RBF and CES with $100 \mathrm{mg} / \mathrm{L}$ of ferric chloride, which boosted it to $122 \mathrm{~L}(\mathrm{~N}) \mathrm{CH}_{4} / \mathrm{kg} \mathrm{COD}$ influent due to the higher COD capture determined with the addition of chemicals (Figure 1).

\section{Fate of organic micropollutants in the RBF and CES systems}

The concentrations of the 18 selected OMPs in the influent of both RBF systems are reported in Table S2. The highest concentrations of OMPs in both WWTPs were observed for the anti-inflammatories IBP and NPX (3.47-4.89 $\mu \mathrm{g} / \mathrm{L})$, although DCF was not detected in either of the two WWTPs. These concentrations are consistent with other concentrations in the literature. ${ }^{13,36,37}$ Musk fragrances (HHCB, AHTN and ADBI) and the endocrine-disrupting compound TCS were detected in the range $0.95-2.16 \mu \mathrm{g} / \mathrm{L}$, in accordance with other authors. ${ }^{36,38,39}$ The four antibiotics (SMX, TMP, ERY, and ROX) and the four neurodrugs (FLX, CBZ, DZP and CTL) were detected in the influent of Blaricum WWTP, whereas SMX and ROX were not detected in the Aarle-Rixtel 
WWTP. In general, the measured concentrations (LOD-235 ng/L) were in the lower

301 range of the literature. ${ }^{36,37,39,40}$ This fact can be explained by the fact that the

302 Netherlands has the lowest human antibiotic consumption rate of Europe. ${ }^{41}$ The

303 concentrations of hormones ranged between LOQ and $57 \mathrm{ng} / \mathrm{L}$, which is the same range

304 of those reported in the literature). ${ }^{39}$

The OMP removal efficiencies achieved in the different evaluated systems (RBF, CPT, and RBF+CES using $100 \mathrm{mg} / \mathrm{L}$ of ferric chloride and CES using $300 \mathrm{mg} / \mathrm{L}$ of ferric chloride) are shown in Figure 4. Only fragrances and TCS were removed in a significant percentage in the evaluated scenarios. In the RBFs of the Blaricum WWTP (WWTP 1), the removal efficiencies of HHCB, AHTN and ADBI were 39\%, 46\% and 34\%, both sludges (in Supporting Information S3, a detailed discussion is included). In the 
improvement in the removal efficiencies of HHCB and AHTN to $96 \%$ and improvement in the removal efficiency of ADBI to $75 \%$, which is similar to those achieved in the CES. For the remaining OMPs, the elimination of different RBF systems ranged from -8 to $14 \%$ (Figure 3). The increase in concentration of some OMPs was likely attributed to the analytical deviation caused by the distinctive characteristics of the wastewaters. These results show agreement with the literature. ${ }^{13,42,43}$

It seems to be a consensus in the literature that most OMPs are poorly removed during coagulation-flocculation processes, however, some exceptions such as musks, a few pharmaceuticals (e.g. DCF) and nonylphenol were found. ${ }^{39}$ Moreover, some authors reported that the different composition of wastewater can play a major role on OMPs removal during CES. For example, high fat content in wastewater was reported to improve the removal of hydrophobic compounds. ${ }^{42}$ Dissolved humic acid could also enhance the elimination of some pharmaceutical compounds, such as DCF or IBP. ${ }^{44}$ On the contrary, the presence of $\mathrm{COD}_{\text {sol }}$, especially low-molecular-weight fractions, can possibly inhibit the OMPs removal due to the preferential removal of $\mathrm{COD}_{\text {sol }}$ through coagulation. Negatively charged $\mathrm{COD}_{\text {sol }}$ could react with positively charged coagulants, leading to a less amount of coagulant available for elimination of OMPs. ${ }^{45}$

Although the system RBF+CES of the proposed alternative did not enable extra removal of hydrophilic compounds compared with conventional settling, it enabled an increase in the removal efficiency of hydrophobic compounds, which achieved results that were as good as those obtained in the CES with higher doses of ferric chloride. 
344 Among the evaluated alternatives, the combination of RBF and CES drove the maximum energy production with the lowest ferric chloride and alkalinity consumption

346 and to the highest OMPs removal. Figure 5 shows a comparison of this alternative with

347 the conventional WWTP scheme in terms of energy production/consumption.

348 In conventional WWTPs, aeration usually consumes the largest energy fraction

349 (maximum of $70 \%),{ }^{4,46}$ which causes a total energy consumption of wastewater in the

350 range $0.6-1.2 \mathrm{kWh} / \mathrm{kg} \mathrm{COD}$ tot, with an average value of $0.9 \mathrm{kWh} / \mathrm{kg} \mathrm{COD}$ tot. $^{47}$

351 Therefore, the treatment of $0.54 \mathrm{kWh} / \mathrm{m}^{3}$ wastewater is needed, considering $0.6 \mathrm{~kg}$

$352 \mathrm{COD}_{\mathrm{tot}} / \mathrm{m}^{3}$ for the Aarle-Rixtel WWTP (Table 1), in accordance with other reported values in the literature. ${ }^{48}$ The potential energy in typical domestic wastewater has been estimated as $4.5 \mathrm{kWh} / \mathrm{kg} \mathrm{COD}$ tot in the influent ${ }^{5,49}$, and the $\mathrm{COD}_{\text {tot }}$ transformed into methane usually does not exceed $30 \%,{ }^{50,51}$ of which a maximum of $35 \%$ is converted to electricity via its combustion. ${ }^{47}$ As approximately $0.47 \mathrm{kWh}$ per $\mathrm{kg}$ of $\mathrm{COD}_{\text {influent }}$ are commonly recovered, a maximum of $50 \%$ of self-produced energy can be achieved $€ / \mathrm{m}^{3}$ for treated wastewater is estimated.

In the proposed scenario (Figure 5b), the electricity demand of the $\mathrm{PN}$-anammox unit was considered to be $60 \%$ of the nitrification-denitrification electricity demand, according to Schaubroeck et al., ${ }^{51}$ which yielded $0.23 \mathrm{kWh} / \mathrm{m}^{3}$ of treated wastewater. The maximum electricity consumption of RBF was reported to be approximately 0.04 $\mathrm{kWh} / \mathrm{m}^{3},{ }^{54}$ and the costs due to pumping and sludge treatment were assumed to be 0.17 $\mathrm{kWh} / \mathrm{m}^{3}$, which is equivalent to those in conventional configurations ${ }^{47}$. Thus, the 
electricity demand was $0.44 \mathrm{kWh} / \mathrm{m}^{3}$, which is $19 \%$ lower than that in the conventional configuration $\left(0.54 \mathrm{kWh} / \mathrm{m}^{3}\right)$. The combination of RBF followed by CEPT enabled $84 \%$ recovery of the $\mathrm{COD}_{\text {tot }}$ of the influent as sludge (Figure 2). During $\mathrm{AD}, 52 \%$ of the influent COD was transformed into methane and yielded electricity generation of 0.82 $\mathrm{kWh}$ per $\mathrm{kg}$ of $\mathrm{COD}_{\text {influent }}\left(0.49 \mathrm{kWh} / \mathrm{m}^{3}\right.$ of wastewater treated), which almost doubles the electricity generation in the conventional WWTP. This fact and the lower electrical requirements of this configuration enable an electrical self-production of 100-110\%. To calculate the operational costs associated with chemical addition, the $\mathrm{FeCl}_{3}$ price was estimated at approximately $220 € /$ ton ${ }^{18}$ and the sodium bicarbonate price was estimated at approximately $200 € /$ ton $(1,400 € /$ ton IC). Two different scenarios were evaluated: in the first scenario, the alkalinity of wastewater was assumed to be sufficiently high bear the consumption produced in CES; thus, the influent to the PNanammox would have an appropriate alkalinity-to-ammonium ratio; in the second scenario, an external alkalinity addition as sodium bicarbonate was considered to compensate its consumption in the CES stage. The first scenario yielded a treatment cost that was 29\% lower than the treatment cost in the conventional WWTP $(0.022$ versus $\left.0.031 € / \mathrm{m}^{3}\right)$. In the second scenario, the calculated treatment costs increased to $0.053 € / \mathrm{m}^{3}$; thus, it was distinctly uncompetitive compared with the conventional WWTP.

\section{Conclusion}

The implementation of rotating belt filters before chemically enhanced settling was proven effective for generating suitable effluents for a nutrient removal stage, 
maximising the energy recovery via the anaerobic digestion of the generated sludges, attaining $110 \%$ of the electrical autarky and achieving OMP removal that is as

390 substantial as that obtained in chemically enhanced settling, and decreasing the required

391 dose3-fold. However, a minimum alkalinity level in wastewaters was shown mandatory

392 to consider this WWTP configuration as more economically favourable with respect to

393 the conventional WWTP configuration.

\section{Acknowledgements}

This work is part of the PIONEER STP project, which is funded by the Water Joint

396 Programming Initiative, a water challenge for a changing world waterworks 2014 co-

397 fund call. The authors belong to the Galician Competitive Research Group ED431C

398 2017/029 and the CRETUS Strategic Partnership (AGRUP2017/01). These programmes

399 are co-funded by FEDER (EU). The authors also thank Mr. Pim Marcelis from CirTec

400 BV and Mrs. Cinzia da Ros from the University of Verona for their technical support. 


\section{References}

4021 A. Mulder, A. A. van de Graaf, L. A. Robertson and J. G. Kuenen, FEMS Microbiol. Ecol., 1995, $403 \quad \mathbf{1 6}, 177-183$.

4042 J. R. Vázquez-Padín, I. Fernández, N. Morales, J. L. Campos, A. Mosquera-Corral and R. Méndez, $405 \quad$ Water Sci. Technol., 2011, 63, 1282-1288.

4063 D. T. Tan and D. Shuai, Environ. Sci. Water Res. Technol., 2015, 1, 546-549.

$4074 \quad$ H. Siegrist, D. Salzgeber, J. Eugster and A. Joss, Water Sci. Technol., 2008, 57, 383-388.

4085 I. Shizas and D. M. Bagley, J. Energy Eng., 2004, 130, 45-53.

$4096 \quad$ S. Aiyuk, I. Forrez, D. K. Lieven, A. van Haandel and W. Verstraete, Bioresour. Technol., 2006, 97, $410 \quad 2225-2241$.

4117 C. J. Ruiken, G. Breuer, E. Klaversma, T. Santiago and M. C. M. Van Loosdrecht, Water Res., 2013, $412 \quad 47,43-48$.

4138 H. Wang, F. Li, A. A. Keller and R. Xu, Water Sci. Technol., 2009, 60, 1803-1809.

4149 H. Ge, D. J. Batstone and J. Keller, Water Res., 2013, 47, 6546-6557.

$41510 \quad$ B. Rusten and H. Ødegaard, Water Sci. Technol., 2006, 54, 31-38.

41611 A. Franchi and D. Santoro, Water Pract. Technol., 2015, 10, 319 LP-327.

41712 V. A. Razafimanantsoa, L. Ydstebo, T. Bilstad, A. K. Sahu and B. Rusten, Water Sci. Technol., 2014, $418 \quad$ 69, $1942-1948$.

41913 M. Carballa, F. Omil, J. M. Lema, M. Llompart, C. García-Jares, I. Rodríguez, M. Gómez and T. $420 \quad$ Ternes, Water Res., 2004, 38, 2918-2926.

42114 D. Crutchik, N. Frison, A. L. Eusebi and F. Fatone, Water Res., 2018, 136, 112-119.

42215 D. S. M. Ghasimi, Y. Tao, M. de Kreuk, B. Abbas, M. H. Zandvoort and J. B. van Lier, Water Res., $423 \quad 2015,87,483-493$.

42416 C. R. Behera, D. Santoro, K. V. Gernaey and G. Sin, Chem. Eng. J., 2018, 334, 1965-1976.

42517 B. Rusten, S. S. Rathnaweera, E. Rismyhr, A. K. Sahu and J. Ntiako, Water Sci. Technol., 2017, 75, $426 \quad 1-10$.

42718 G. De Feo, S. De Gisi and M. Galasso, Desalination, 2008, 230, 229-238.

42819 J. Heffron and B. K. Mayer, Environ. Sci. Water Res. Technol., 2016, 2, 443-459.

$42920 \quad$ F. Ju, Y. Wang, F. T. K. Lau, W. C. Fung, D. Huang, Y. Xia and T. Zhang, Appl. Microbiol. $430 \quad$ Biotechnol., 2016, 100, 8975-8982.

$43121 \quad$ B. Gao, B. Liu, T. Chen and Q. Yue, J. Hazard. Mater, 2011, 187, 413-420. 
C. Holliger, M. Alves, D. Andrade, I. Angelidaki, S. Astals, U. Baier, C. Bougrier, P. Buffière, M. Carballa, V. De Wilde, F. Ebertseder, B. Fernández, E. Ficara, I. Fotidis, J. C. Frigon, H. F. De Laclos, D. S. M. Ghasimi, G. Hack, M. Hartel, J. Heerenklage, I. S. Horvath, P. Jenicek, K. Koch, J. Krautwald, J. Lizasoain, J. Liu, L. Mosberger, M. Nistor, H. Oechsner, J. V. Oliveira, M. Paterson, A. Pauss, S. Pommier, I. Porqueddu, F. Raposo, T. Ribeiro, F. R. Pfund, S. Strömberg, M. Torrijos, M. Van Eekert, J. Van Lier, H. Wedwitschka and I. Wierinck, Water Sci. Technol., 2016, 74, 25152522 .

APHA, Standard Methods for the Examination of Water and Wastewater, 21 st ed. American Public Health Association/American Water Works Association/Water Environment Federation, Washington DC, USA., American Public Health Association, Washington DC, 2005.

E. Fernandez-Fontaina, I. Pinho, M. Carballa, F. Omil and J. M. Lema, Biodegradation, 2013, 24, $165-177$.

L. Paredes, C. Alfonsin, T. Allegue, F. Omil and M. Carballa, Chem. Eng. J., 2018, 345, 79-86.

S. Puig, M. C. M. van Loosdrecht, A. G. Flameling, J. Colprim and S. C. F. Meijer, Water Res., 2010, 44, 3375-3384.

B. Paulsrud, B. Rusten and B. Aas, Water Sci. Technol., 2014, 69, 560-565.

M. Jia, C. M. Castro-Barros, M. K. H. Winkler and E. I. P. Volcke, Environ. Sci. Water Res. Technol., , DOI:10.1039/c8ew00125a.

Metcalf \& Eddy, Wastewater Engineering: Treatment and Reuse, New York, 2003. Mosquera-Corral, Sep. Purif. Technol., 2017, 186, 55-62. Energy Rev., 2016, 58, 1486-1499.

S. Terzić, I. Senta, M. Ahel, M. Gros, M. Petrović, D. Barcelo, J. Müller, T. Knepper, I. Martí, F. Ventura, P. Jovančić and D. Jabučar, Sci. Total Environ., 2008, 399, 66-77. Chemosphere, 2011, 82, 1116-1123. 
$46640 \quad$ P. Verlicchi, M. Al Aukidy and E. Zambello, Sci. Total Environ., 2012, 429, 123-155.

46741 European Centre for Disease Prevention and Control, Surveillance of antimicrobial consumption in $468 \quad$ Europe, 2014.

46942 S. Suarez, J. M. Lema and F. Omil, Bioresour. Technol., 2009, 100, 2138-2146.

$47043 \quad$ S. K. Behera, H. W. Kim, J. E. Oh and H. S. Park, Sci. Total Environ., 2011, 409, 4351-4360.

$47144 \quad$ N. Vieno, T. Tuhkanen and L. Kronberg, Environ. Technol., 2006, 27, 183-192.

$47245 \quad$ K. J. Choi, S. G. Kim and S. H. Kim, J. Hazard. Mater, 2008, 151, 38-43.

47346 D. Rosso, L. E. Larson and M. K. Stenstrom, Water Sci. Technol., 2008, 57, 973-978.

47447 Y. Zhou, D. Q. Zhang, M. T. Le, A. N. Puah and W. J. Ng, J. Water Clim. Chang., 2013, 4, 1-10.

47548 R. Cano, S. I. Pérez-Elvira and F. Fdz-Polanco, Appl. Energy, 2015, 149, 176-185.

47649 E. S. Heidrich, T. P. Curtis and J. Dolfing, Environ. Sci. Technol., 2011, 45, 827-832.

$47750 \quad$ J. Wan, J. Gu, Q. Zhao and Y. Liu, Sci. Rep., 2016, 6, 1-9.

$47851 \quad$ J. M. Garrido, M. Fdz-Polanco and F. Fdz-Polanco, Water Sci. Technol., 2013, 67, 2294-2301.

$47952 \quad$ STOWA, Influent fijnzeven in RWZI's 2010-19, 2010.

$48053 \quad$ T. Schaubroeck, H. De Clippeleir, N. Weissenbacher, J. Dewulf, P. Boeckx, S. E. Vlaeminck and B. $481 \quad$ Wett, Water Res., 2015, 74, 166-179.

$48254 \quad$ Salsnes, Eco-Efficient Solids Separation Benchmarking water solutions, 2016. 
484 Table 1. Physicochemical characteristics of influent and effluent in rotating belt sieves 485 from Blaricum and Aarle-Rixtel wastewater treatment plants $(n=3)$.

486 Table 2. Physicochemical characteristics of dewatered sieved sludge generated in 487 rotating belt sieves of Blaricum and Aarle-Rixtel wastewater treatment plants $(n=3)$.

488 Table 3. Calculated electricity and chemical operational costs of the proposed WWTP 489 configuration. 


\section{Figures captions}

491 Fig. 1. Influence of ferric chloride dose on the removal of soluble ( $\square$ ) and particulate

492 ( $\square$ ) COD and TSS (•) on raw wastewater of Aarle-Rixtel WWTP. 0 mg FeCl $/ 2$ refers 493 to conventional settling without chemicals.

494 Fig. 2. Influence of ferric chloride dose on the removal of soluble ( $\square$ ) and particulate

495 ( $\square$ ) COD and TSS (•) on the RBF effluent of wastewater of Aarle-Rixtel WWTP. 0 mg $496 \mathrm{FeCl}_{3} / \mathrm{L}$ refers to conventional settling without chemicals.

497 Fig. 3. Average BMP results of dewatered sieved sludge ( $\square$ ), conventional settling

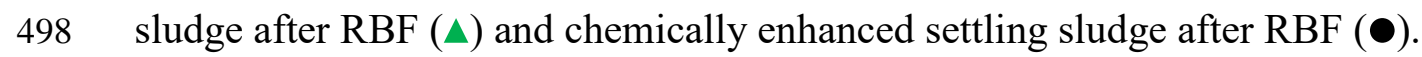

499 Fig. 4. Removal efficiencies of the organic micropollutants in RBF system in WWTP 1

500 (घ), in RBF in WWTP 2 (目), in CPT in WWTP 2 (घ), RBF + CES in WWTP 2 (圆), 501 and CES in WWTP 2 ( $\square)$.

502 Fig. 5. COD balance (in relation to $1 \mathrm{~kg}$ in the influent) and energy flows for the traditional WWTP configuration (adapted from Wan et al. ${ }^{50}$ ) and the proposed WWTP configuration. * Represents the energy required for sludge management and pumping, 


\begin{tabular}{|c|c|c|c|c|}
\hline & \multicolumn{2}{|c|}{ Blaricum WWTP } & \multicolumn{2}{|c|}{ WWTP Aarle-Rixtel } \\
\hline & Influent & Effluent & Influent & Effluent \\
\hline $\mathrm{TS}(\mathrm{mg} / \mathrm{L})$ & $770 \pm 30$ & $610 \pm 20$ & $1260 \pm 0$ & $1140 \pm 10$ \\
\hline VS (mg/L) & $600 \pm 20$ & $440 \pm 20$ & $570 \pm 5$ & $450 \pm 20$ \\
\hline TSS (mg/L) & $320 \pm 10$ & $160 \pm 0$ & $275 \pm 5$ & $145 \pm 10$ \\
\hline VSS (mg/L) & $300 \pm 20$ & $150 \pm 0$ & $255 \pm 10$ & $130 \pm 5$ \\
\hline $\mathrm{COD}_{\text {tot }}\left(\mathrm{mg} \mathrm{O}_{2} / \mathrm{L}\right)$ & $680 \pm 10$ & $440 \pm 10$ & $600 \pm 30$ & $470 \pm 10$ \\
\hline $\mathrm{COD}_{\text {sol }}\left(\mathrm{mg} \mathrm{O}_{2} / \mathrm{L}\right)$ & $230 \pm 10$ & $220 \pm 10$ & $260 \pm 20$ & $240 \pm 10$ \\
\hline TKN-N (mg/L) & $87 \pm 2$ & $75 \pm 1$ & $75 \pm 4$ & $69 \pm 6$ \\
\hline TAN-N (mg/L) & nd & nd & $67 \pm 3$ & $61 \pm 4$ \\
\hline
\end{tabular}

507 TS: total solids; VS: volatile solids; TSS: total suspended solids; VSS: volatile 508 suspended solids; COD: chemical oxygen demand; TKN-N: total Kjeldahl nitrogen, 509 TAN-N: total ammonium nitrogen, n.d.: not determined. 


\section{Blaricum WWTP Aarle-Rixtel WWTP}

\begin{tabular}{lll}
\hline TS $(\mathrm{g} / \mathrm{kg})$ & $215 \pm 10$ & $279 \pm 10$ \\
$\mathrm{VS}(\mathrm{g} / \mathrm{kg})$ & $200 \pm 10$ & $261 \pm 10$ \\
$\mathrm{COD}$ tot $(\mathrm{g} / \mathrm{kg})$ & $273 \pm 18$ & $350 \pm 20$ \\
$\mathrm{TKN}-\mathrm{N}(\mathrm{g} / \mathrm{kg})$ & $3.3 \pm 0.2$ & $4.2 \pm 0.1$ \\
\hline
\end{tabular}

512 TS: total solids; VS: volatile solids; COD tot: total chemical oxygen demand; TKN: total 513 Kjeldahl nitrogen. 
$514 \quad$ Table 3

\begin{tabular}{lcc} 
& Alkalinity supply & No alkalinity supply \\
\hline Electricity requirements $\left(\mathrm{kWh} / \mathrm{m}^{3}\right)$ & 0 & 0 \\
Ferric chloride dosage $\left(\mathrm{kg} / \mathrm{m}^{3}\right)$ & 0.1 & 0.1 \\
Alkalinity supply $\left(\mathrm{g} \mathrm{IC} / \mathrm{m}^{3}\right)$ & 0.022 & 0 \\
Ferric chloride cost $\left(€ / \mathrm{m}^{3}\right)$ & 0.022 & 0.022 \\
Sodium bicarbonate $\operatorname{cost}\left(€ / \mathrm{m}^{3}\right)$ & 0.031 & 0 \\
Operational costs $\left(€ / \mathrm{m}^{3}\right)$ & 0.053 & 0.022 \\
\hline
\end{tabular}




\section{$515 \quad$ Figure 1}

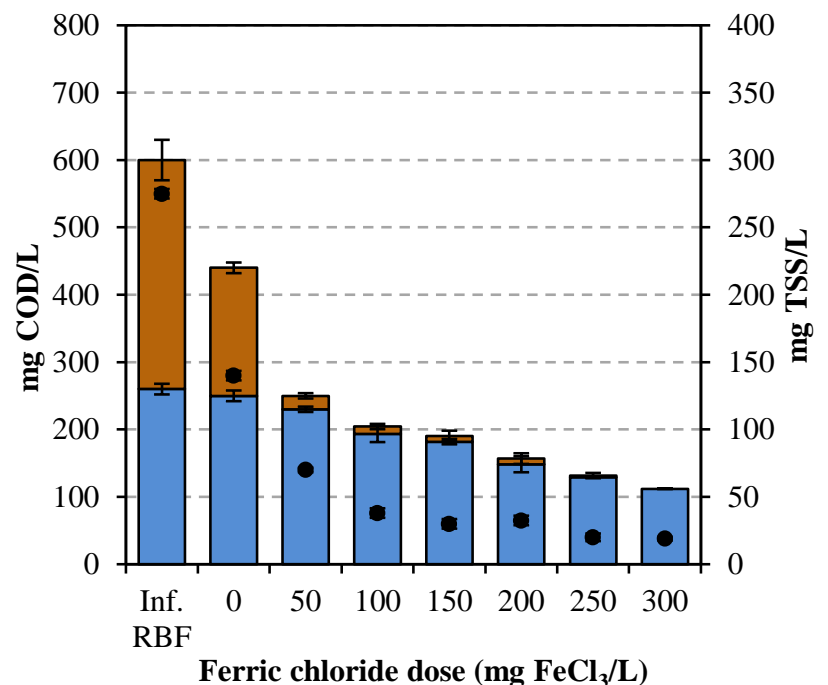




\section{$516 \quad$ Figure 2}

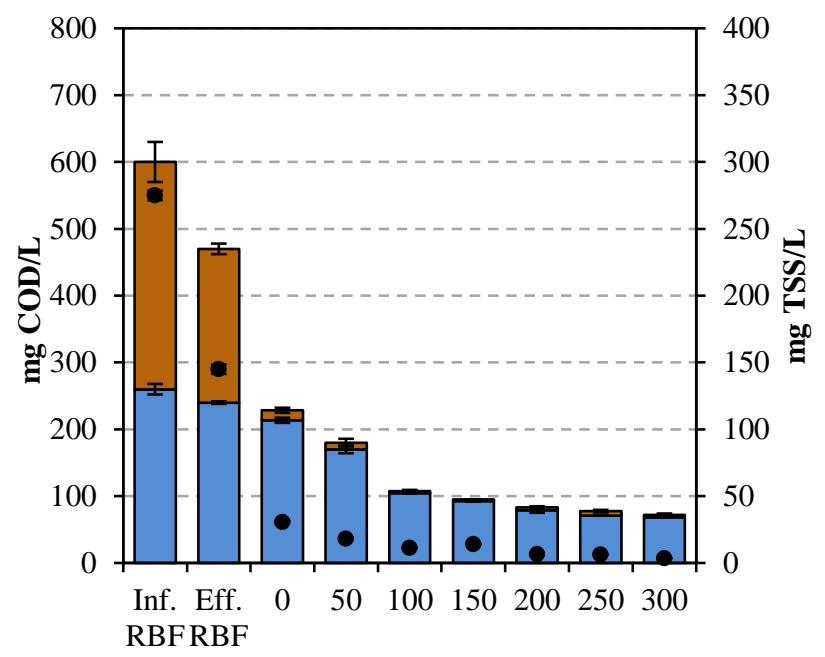

Ferric chloride dose $\left(\mathrm{mg} \mathrm{FeCl}_{3} / \mathrm{L}\right)$ 


\section{$517 \quad$ Figure 3}

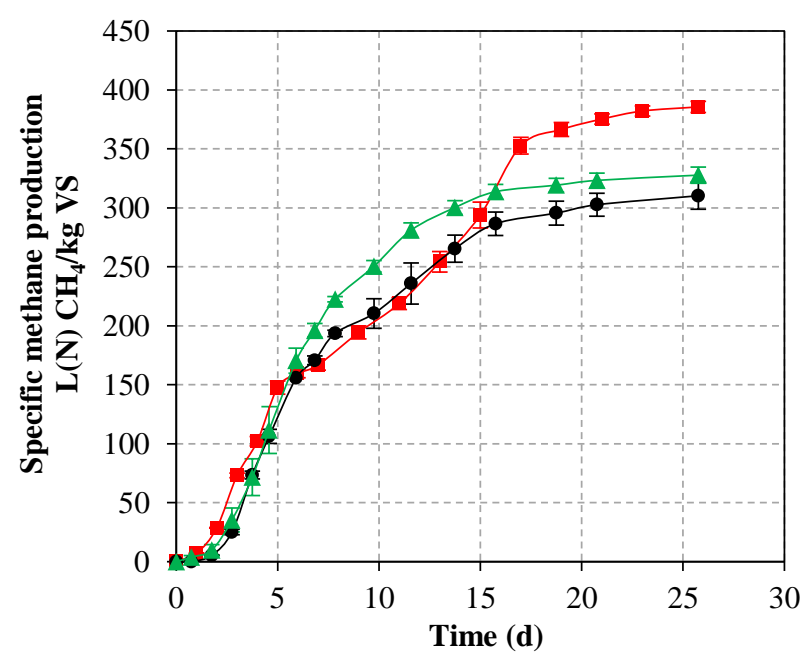


$518 \quad$ Figure 4

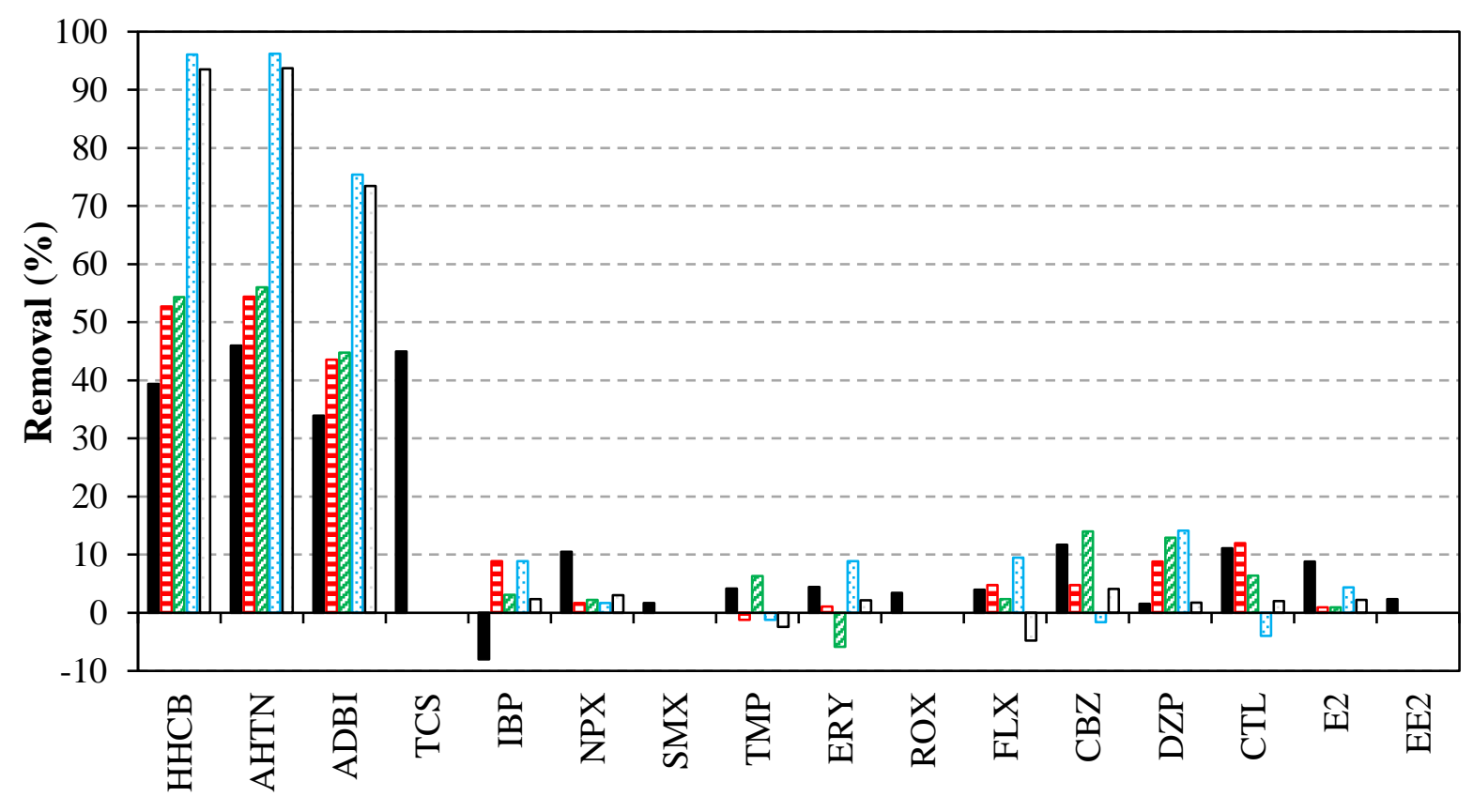



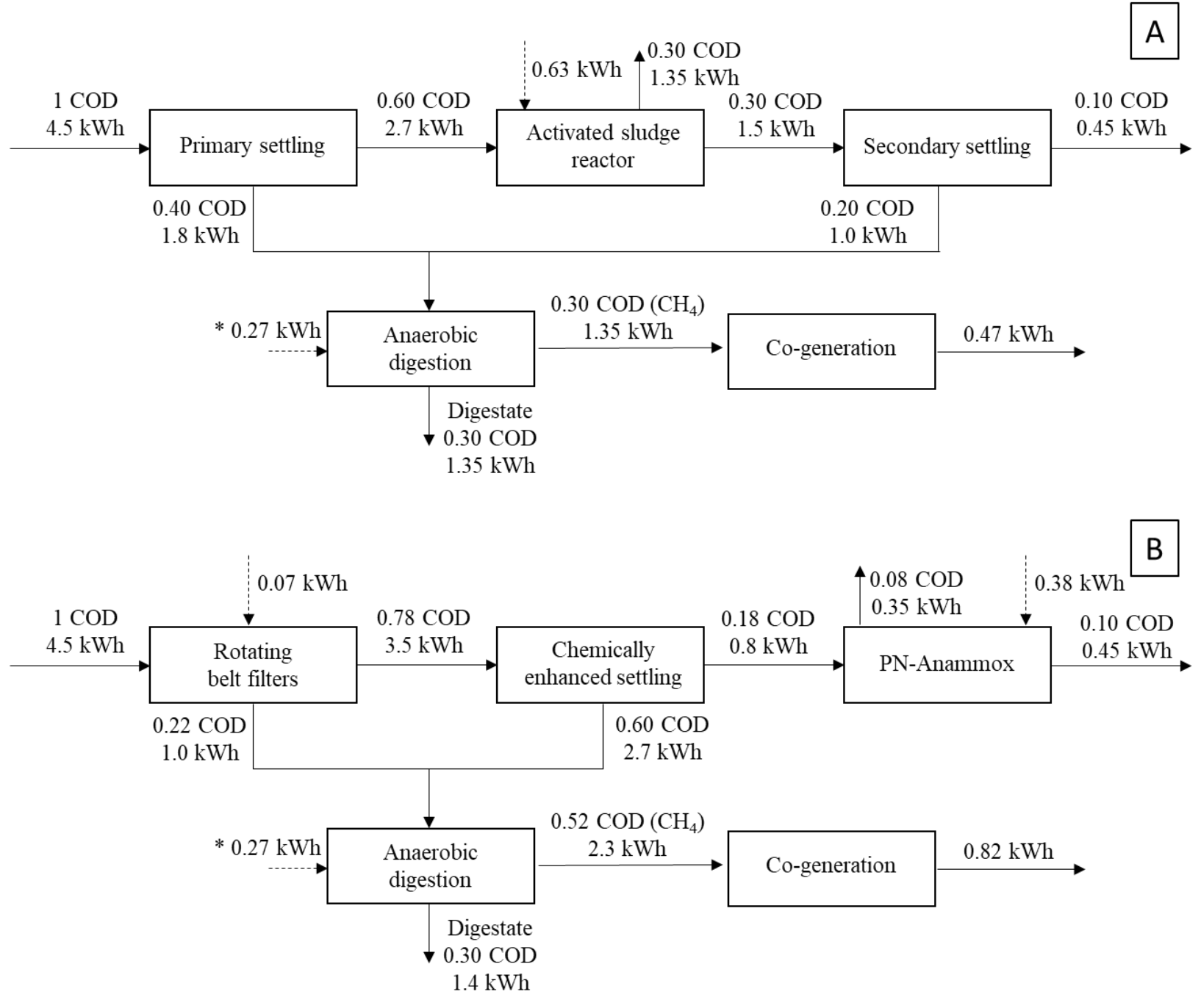